\title{
Gas Chromatography-Mass Spectrometry (GC-MS) based Metabolomics of Promising Chickpea Genotypes against Callosobruchus chinensis (L.)
}

\author{
M.S. Sai Reddy ${ }^{1}$, Meena Agnihotri², S.D. Divija ${ }^{3}$, Babita Belal ${ }^{4}$, Somala Karthik ${ }^{1}$
}

10.18805/LR-4648

\begin{abstract}
Background: The pulse beetle, Callosobruchus chinensis L. is one of the main biotic threats to chickpea in both field and storage in the world. The evaluation of chickpea genotypes for pulse beetle resistance has increased motivation for the identification and application of host plant resistance as a critical component of pest management.

Methods: In the present study, different chickpea genotypes were evaluated under laboratory conditions to identify the antixenosis, antibiosis and GC-MS based untargeted metabolomics of promising chickpea genotypes to the $C$. chinensis.

Result: Genotype NBeG1004 (36.61 eggs/100 seeds) was less prone to egg laying, while ICCV14872 (180.45 eggs/100 seeds) was the most preferred. However, maximal developmental periods, minimum per cent adult emergence and growth index was observed in ICCV92944 Genotype HC1 showed substantial resistance with maximum phenolic, flavonoid and protease inhibitors content. The results revealed that presence of 9-Octadecenoic acid $(Z)$ in $\mathrm{HC} 1$ conferred resistance to $C$. chinensis. These results show assurance for incorporation into an IPM program against $C$. chinensis.
\end{abstract}

Key words: 9-Octadecenoic acid (Z), Callosobruchus chinensis, Chickpea, GC-MS.

\section{INTRODUCTION}

Chickpea (Cicer arietinum L.) (Fabaceae) is a legume crop consumed all over the world, exclusively in Afro-Asian countries. After dry beans and field beans, it is the world's third most-produced pulse crop. Globally, India is the largest producer of chickpeas, accounting for 65 per cent $(9.07$ million tonnes) of total production (Merga and Haji, 2019). They are in high demand due to their high nutritional value and low cost of protein, as well as their potentially health-beneficial phytochemicals.

However, it was affected by several biotic and abiotic factors. Among biotic factors, pulse beetle Callosobruchus chinensis (L.) (Chrysomelidae: Coleoptera) is the dominant insect pest that causes 55 to 60 per cent losses in seed weight and 45.50 to 66.30 per cent losses in protein content and 5 to 10 per cent losses during storage (Lal and Verma, 2007). Seeds damaged by $C$. chinensis are unfit for human consumption and sowing in subsequent seasons. Although it is being effectively controlled by insecticides all over the world, chemical control could led to the development of resistance, have negative impact on natural enemies and expensive (Liu and Trumble, 2007). Therefore, it is important to find alternative methods for control, such as host plant resistance, which can be the foundation of an IPM program. Moreover, the use of resistant cultivars may offer a longterm solution for controlling this pest. Therefore, the identification and development of improved genotypes with tolerance to $C$. chinensis will be a cost effective and environmentally friendly approach for reducing yield losses. On this basis, the current study sought to comprehend the
${ }^{1}$ Department of Entomology, Dr. Rajendra Prasad Central Agricultural University, Pusa-848 125, Bihar, India.

2Department of Entomology, G.B. Pant University of Agriculture and Technology, Pantnagar-263 145, Uttarakhand, India.

${ }^{3}$ Department of Entomology, University of Agricultural Sciences, Bangalore-560 065, Karnataka, India.

${ }^{4}$ Department of Chemistry, G.B. Pant University of Agriculture and Technology, Pantnagar-263 145, Uttarakhand, India.

Corresponding Author: M.S. Sai Reddy, Department of Entomology, Dr. Rajendra Prasad Central Agricultural University, Pusa-848 125, Bihar, India. Email: mssaireddy@gmail.com

How to cite this article: Reddy, M.S.S., Agnihotri, M., Divija, S.D., Bela, B. and Karthik, S. (2021). Gas Chromatography-Mass Spectrometry (GC-MS) based Metabolomics of Promising Chickpea Genotypes against Callosobruchus chinensis (L.). Legume Research. 44(11): 1371-1378. DOI: 10.18805/LR-4648.

Submitted: 29-04-2021 Accepted: 03-07-2021 Online: 14-08-2021

significance of host plant resistance (antixenosis, antiobiosis and untargeted metabolomics) in identifying pulse beetle resistant lines.

\section{MATERIALS AND METHODS}

Screening of eleven chickpea genotypes (ICC07104, ICCV07108, ICCV09103, ICCV14872, ICCV97105, HC1, NBeG1004, GLW48, GL25016, JG11 and ICCV92944) along with three checks viz. standard local resistant check (PG 186), national susceptible check (ICC3137) and national resistant check (ICCL86111) against C. chinensis under 'No choice' 
Gas Chromatography-Mass Spectrometry (GC-MS) based Metabolomics of Promising Chickpea Genotypes against...

were performed in the Department of Entomology and Department of Chemistry at GBPUAT, Pantnagar during 2017-18. These genotypes were selected out of 48 as promising entries of field level screening against Helicoverpa armigera (Reddy and Agnihotri, 2018). On the basis of unipectinate antennae in males and serrated antennae with longer wide abdomen in females, five pairs of one-day old (5 males and 5 females were separated in a plastic jars with 100 number weighed seeds covered with the muslin cloth. The culture was reared on healthy, sterilized seeds of chickpea variety, PG186 and maintained at $30 \pm 1^{\circ} \mathrm{C}, 60 \pm 5 \%$ relative humidity with photoperiod of $12: 12$ hours (light and dark) for three generations prior to experimentation to make sure that they were genetically and phenotypically identical (Malaikozhundan and Thiravia, 2012). The experiment was carried out in completely randomized design (CRD) and the beetles were grown in moderately crowded conditions to ensure proper development and equal size of the resultant adults.

After three days of release of insect, eggs were counted at the time of removal of adults from the jars using the magnifying glass. Adult emergence was determined by counting the number of adults emerged from the seeds of each genotype; mean developmental period is the time needed for the emergence of 50 per cent of adults (Howe, 1971). Based on the growth index (Jackai and Singh, 1988), genotypes were classified as resistant $(\leq 0.040-0.050)$, moderately resistant $(0.051-0.055)$, moderately susceptible (0.056-0.060), susceptible (0.061-0.065) and highly susceptible (0.066-0.070 $\geq$ ) (Sulehrie et al., 2003).

\section{Antixenosis and antibiosis of promising chickpea geno-} types to the $C$. chinensis

\section{Antixenosis}

Physical characteristics like texture, thickness, colour and shape of seeds were recorded on the visual basis. Data on length, width and thickness of pods were recorded using electronic vernier calipers on the three uniformly developed pods of each test genotype per replication.

\section{Antibiosis}

$10 \mathrm{gm}$ of mature seed material was crushed using pestle mortar with liquid nitrogen and soaked for 48 hours in 100 $\mathrm{ml}$ of methanol. The crude methanol was extracted using Whatman No.1 filter paper and evaporated the solvent at $50^{\circ} \mathrm{C}$. Final concentration $(0.1 \mathrm{mg} / \mathrm{ml})$ of the extract was used for the assessment of total phenols, flavonoids and tannins. For Phenols: Folin-Ciocalteu's reagent was used to estimate the total phenolic content (TPC) of each extract (Chandrasekara and Shahidi, 2010). A standard curve was prepared using gallic acid to determine the TPC as $\mu \mathrm{mol}$ gallic acid equivalents (GAE)/g of dry matter. For flavonoids: Colorimetric method was used to estimate the total flavonoids content (Kim et al., 2003). Total flavonoid content (TFC) was expressed as $\mathrm{mg}$ quercetin equivalents $/ 100 \mathrm{~g}$ dry matter. Condensed tannins: Vanillin/ $\mathrm{HCl}$ assay was used to estimate the proanthocyanidins content (Sun et al., 1998). Total proanthocyanidin content (TPCC) was expressed as catechin equivalents $(\mathrm{mg} / \mathrm{g})$ using a catechin $(0.06-0.3 \mathrm{mg} / \mathrm{ml})$ standard curve.

For proteins: Proteins were extracted using $\mathrm{NaOH}$ solution and estimated as per the procedure given by Lowry et al. (1951). Protein content (PC) in samples was calculated from the standard curve prepared by taking different concentrations of bovine serum albumin (BSA) dissolved in $0.1 \mathrm{~N} \mathrm{NaOH}(20-100 \mu \mathrm{g})$. For Trypsin Inhibitor: Trypsin Inhibitor Content (TIC) done through the method specified by Hajela et al. (1999).

\section{GC-MS for bioactive compounds in chickpea genotypes seeds}

GC-MS analysis of selected chickpea genotype seeds (Resistant genotypes (ICCV92944, HC1), susceptible genotype (JG11), susceptible check genotype (ICC3137) and resistant check genotype (PG186) for bio active compounds was performed in Advanced Instrumental Research Facility (AIRF), Jawaharlal Nehru University (JNU) New Delhi. 10 gram sample of selected genotype was crushed with pestle mortar in the presence of liquid nitrogen to convert it into powder form and soaked overnight in $25 \mathrm{ml}$ of methanol. The extract was then filtered through What man No. 1 filter paper and subjected to GC-MS. The individual components form the seeds were identified based on the retention time. It was compared with the components known from the NIST library database (U.S. Department of Commerce) version2011. The data were obtained on a Shimadzu GCMS-QP2010 plus system using $A B$ inno-wax column.

\section{Statistical analysis}

Simple correlation and Tukey's HSD test (SPSS 16.0) for comparing means significantly at the 5 per cent level values were calculated.

\section{RESULTS AND DISCUSSION}

\section{Screening of chickpea genotypes against $\boldsymbol{C}$. chinensis}

The selected genotypes were screened by using no choice test under storage conditions and recorded the minimum numbers of eggs on NBeG1004 (36.61 eggs/100 seeds) followed by ICCV97105 (48.37). These results are well supported by findings of Kamble et al. (2016) who reported the highest number of eggs (31.33 eggs/30 seeds) on cultivar PG-5 whereas cultivar Vijay (17.75) recorded the lowest number of eggs. The lowest number of adult emergences was recorded on ICCV97105 (11.07 adults/100 seeds) followed by NBeG1004 (11.50), ICCV07108 (12.49) and ICCV92944 (14.48). The developmental period of C. chinensis on ICCV92944 was observed to be 28.67 days which was at par with NBeG1004 (27.00), HC1 (26.67) and ICC07104 (26.67) and prolonged developmental period with reduced oviposition and adult emergence were recorded in genotype ICCV92944 specifies that its resistance based on non-preference for oviposition. These results are supported 
by Ahmad et al. (2016) who recorded maximum (32.33) and minimum developmental period (28.67) of pulse beetle in chickpea genotypes.

The lowest growth index (GI) of $C$. chinensis was observed in ICCV92944 (0.046) which was at par with HC1 (0.047), ICCV97105 (0.056) and ICC07104 (0.050). Whereas, highest GI (0.073) was observed in JG11 (0.073). These results are in agreement with the observations of Soumia et al. (2017) who reported GI of $C$. analis ranging from 0.042-0.09 in green gram genotypes. The minimum per cent weight loss was recorded on ICCV07108 (4.22) followed by ICCV92944 (10.71), HC1 (11.23). These results are well supported by findings of Raghuwanshi et al. (2016) who recorded maximum weight loss (24.98) in gram genotype SG-98310.

\section{Antixenosis of chickpea genotypes and their correlation with biological parameters of $C$. chinensis}

The physical/morphological seed parameters (colour, shape, texture, seed coat thickness and 100 seed weight) of eleven promising chickpea genotypes were given in Table 1. It has been observed that all the chickpea genotypes varied significantly for resistance to $C$. chinensis. The minimum number of eggs was detected on NBeG1004 having smooth and bold sized brown seeds. However, maximum number of eggs was laid on ICCV14872 having smooth, dark brown coloured bold seeds. These observations are in partially to with the findings of Shaheen et al. (2006), who reported that genotypes with hard, rough, wrinkled and thick seed coat serve as a barrier to pulse beetle as compared with those having smooth, soft and thin seed coat.

The morphological characters of the genotypes revealed that, there was a significant positive correlation $(P<0.01)$ observed between number of eggs laid and number of adults emerged $\left(r=0.898^{\star *}\right)$, positive correlation growth index $(r=0.429)$ and positive correlation with the seed weight loss (0.428). Similarly, growth index showed a strong positive correlation with number of adults emerged $\left(r=0.754^{* *}\right)$ and significant positive correlated to weight loss $\left(0.627^{\star}\right)$ (Table 2).

\section{Metrics of antibiosis and their correlation with GI of $C$. chinensis}

The highest TPC was observed in GL25016 (2.36 mg/g) followed by ICCV 14872 (2.14 mg/g) and ICC07104 (1.81 $\mathrm{mg} / \mathrm{g}$ ) (Table 3) (Fig 1). The genotypes with higher phenolic content recorded low growth index. The phenols may affect the metabolic enzymes and act as an antimetabolic factor and might have contributed to resistance mechanism as they must have inhibitory role on the development of $C$. chinensis (Ghosal et al., 2004). Whereas, highest TFC was observed in $\mathrm{HC} 1(0.324 \mathrm{mg} / \mathrm{g})$ which recorded lowest growth index as compared to checks ICC3137 $(0.298 \mathrm{mg} / \mathrm{g})$, ICCL86111 $(0.233 \mathrm{mg} / \mathrm{g}), \mathrm{PG} 186(0.463 \mathrm{mg} / \mathrm{g})$. Flavonoids isolated from rice bean seeds have inhibitory effects against growth and development of $C$. chinensis and $C$. maculatus (Somta et al., 2006). The maximum TPCC was recorded from

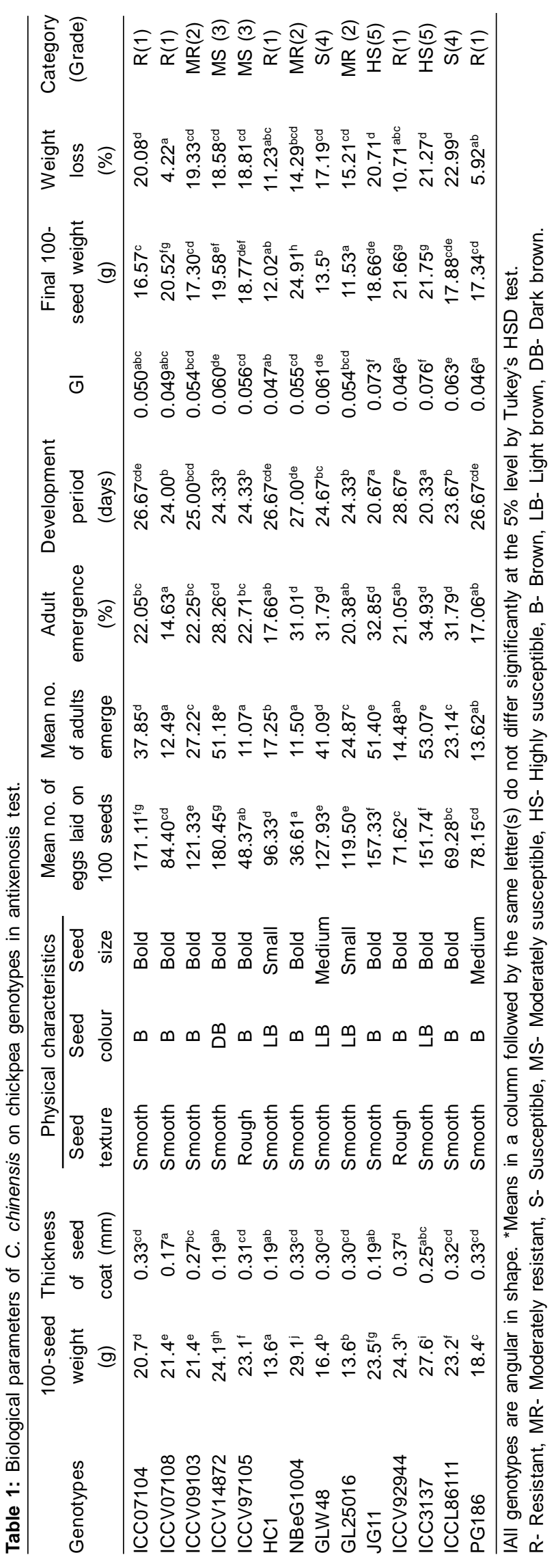


Gas Chromatography-Mass Spectrometry (GC-MS) based Metabolomics of Promising Chickpea Genotypes against...

ICC07104 $(0.393 \mathrm{mg} / \mathrm{g})$ with moderately low growth index (0.050). The results are in cogent evidence with Khattab and Arntfield (2009) studies who stated that tannins are secondary metabolites which impede the gastrointestinal enzymes which results in the lower digestibility of important nutrients especially proteins and starch. The highest PC was recorded from the genotype JG11 (35.83 g/100g seed) with high growth index (0.073) signifying that the genotype was more preferred by $C$. chinensis. Deepika et al. (2020) reported highest trypsin inhibitor in JG315. The maximum TIC was recorded from NBeG1004 $(38.08 \mathrm{IU} / \mathrm{g})$ with lowest growth index. Tamhane et al. (2005) reported that the ingestion of trypsin inhibitor resulted in the reduced fecundity and fertility causing decrease in the insect population.

The growth index of $C$. chinenis had significant negative correlation with trypsin inhibitor $\left(-0.633^{*}\right)$. These results were in support of Landerito et al. (1993), who reported high levels of accumulation of trypsin inhibitors in many bruchid-resistant varieties of mungbean.

\section{Metabolomics of genotypes through GC-MS}

Resistant genotypes (ICCV92944, HC1), susceptible geno type (ICC3137) and resistant genotype (PG186) were subjected to GC-MS for observing the metabolic substances which are responsible for resistance/susceptibility to $C$. chinensis. A total of 35 (ICCV92944), 34 (HC1), 24 (JG 11), 39 (ICC3137) and 32 (PG186) bioactive compounds have been identified through the GC-MS analysis based on the retention time and percent area (Fig 2, 3, 4, 5, 6).

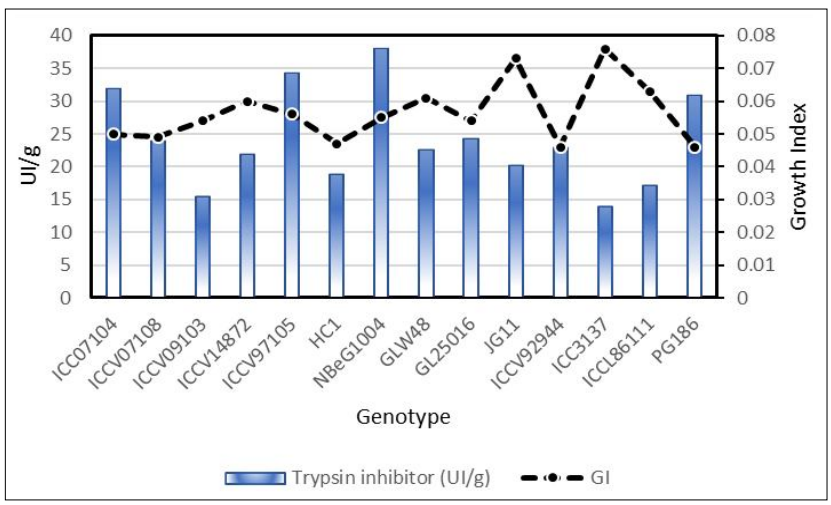

Fig 1: Effect of total trypsin inhibitor content of mature seeds on growth index of $C$. chinensis.

Table 2: Correlation of antixenosis of chickpea genotypes with biological parameters of $C$. chinensis.

\begin{tabular}{|c|c|c|c|c|c|c|}
\hline Variable & $\begin{array}{l}\text { Seed coat } \\
\text { thickness }(\mathrm{mm})\end{array}$ & $\begin{array}{l}100 \text { seed } \\
\text { weight }(\mathrm{g})\end{array}$ & $\begin{array}{l}\text { No. of } \\
\text { egg laid }\end{array}$ & $\begin{array}{c}\text { No. of adult } \\
\text { emerged }\end{array}$ & $\begin{array}{l}\text { Growth } \\
\text { index }\end{array}$ & $\begin{array}{l}\text { Weight } \\
\text { loss (\%) }\end{array}$ \\
\hline Seed coat thickness (mm) & - & - & - & - & - & - \\
\hline 100 seed weight $(\mathrm{g})$ & $0.105^{N S}$ & - & - & - & - & - \\
\hline No. of egg laid & $-0.425^{N S}$ & $-.111^{\mathrm{NS}}$ & - & - & - & - \\
\hline No. of adult emerged & $-0.370^{N S}$ & $0.148^{\mathrm{NS}}$ & $0.898^{* *}$ & - & - & - \\
\hline Growth index & $-0.283^{N S}$ & $0.426^{\mathrm{NS}}$ & 0.429 & $0.754^{\star *}$ & - & - \\
\hline Weight loss (\%) & $0.075^{\mathrm{NS}}$ & $0.297^{\mathrm{NS}}$ & 0.428 & $0.627^{*}$ & $0.710^{*}$ & - \\
\hline
\end{tabular}

** Significant at $1 \%$, ${ }^{\star}$ Significant at $5 \%$, NS- Non-significant.

Table 3: Antibiosis of chickpea genotypes and their correlation with GI of $C$. chinensis.

\begin{tabular}{|c|c|c|c|c|c|}
\hline Genotypes & $\mathrm{TPC}(\mathrm{mg} / \mathrm{g})$ & TFC $(\mathrm{mg} / \mathrm{g})$ & TPCC $(\mathrm{mg} / \mathrm{g})$ & Protein $(\mathrm{g} / 100 \mathrm{~g})$ & TIC (UI/g) \\
\hline ICC07104 & $1.81 \pm 0.25^{\text {cde }}$ & $0.231 \pm 0.05^{\mathrm{bcd}}$ & $0.393 \pm 0.02^{e}$ & $17.50 \pm 1.50^{\mathrm{a}}$ & $32.04 \pm 0.18^{g h}$ \\
\hline ICCV07108 & $1.41 \pm 0.07^{b c}$ & $0.268 \pm 0.01^{\text {bcde }}$ & $0.270 \pm 0.03^{a b}$ & $26.17 \pm 0.29^{e}$ & $23.94 \pm 0.05^{\dagger}$ \\
\hline ICCV09103 & $1.71 \pm 0.13^{\mathrm{cd}}$ & $0.227 \pm 0.02^{\mathrm{bcd}}$ & $0.343 \pm 0.02^{\mathrm{bcd}}$ & $19.92 \pm 1.13^{b}$ & $15.47 \pm 0.08^{\mathrm{ab}}$ \\
\hline ICCV14872 & $2.14 \pm 0.07^{\mathrm{de}}$ & $0.276 \pm 0.01^{\text {cde }}$ & $0.263 \pm 0.05^{\mathrm{a}}$ & $23.08 \pm 1.23^{d}$ & $21.95 \pm 0.21^{\text {def }}$ \\
\hline ICCV97105 & $0.89 \pm 0.07^{\mathrm{ab}}$ & $0.233 \pm 0.01^{\mathrm{bcd}}$ & $0.353 \pm 0.02^{\text {cde }}$ & $27.33 \pm 0.76^{\mathrm{e}}$ & $34.29 \pm 0.05^{\mathrm{h}}$ \\
\hline $\mathrm{HC} 1$ & $1.32 \pm 0.13^{\mathrm{abc}}$ & $0.324 \pm 0.01^{\mathrm{e}}$ & $0.270 \pm 0.01^{\mathrm{ab}}$ & $32.50 \pm 0.25^{\dagger}$ & $18.92 \pm 0.29^{c d}$ \\
\hline NBeG1004 & $1.54 \pm 0.27^{c}$ & $0.197 \pm 0.05^{\mathrm{ab}}$ & $0.313 \pm 0.02^{\mathrm{abcd}}$ & $26.75 \pm 0.25^{\mathrm{e}}$ & $38.08 \pm 0.13^{i}$ \\
\hline GLW 48 & $1.67 \pm 0.30^{\mathrm{cd}}$ & $0.213 \pm 0.01^{b c}$ & $0.363 \pm 0.02^{\text {cde }}$ & $33.25 \pm 0.66^{f}$ & $22.59 \pm 0.19^{e f}$ \\
\hline GL25016 & $2.36 \pm 0.13^{e}$ & $0.233 \pm 0.02^{\mathrm{bcd}}$ & $0.390 \pm 0.04^{\mathrm{e}}$ & $20.58 \pm 0.29^{c}$ & $24.31 \pm 0.21^{f}$ \\
\hline JG11 & $0.80 \pm 0.13^{a}$ & $0.121 \pm 0.01^{\mathrm{a}}$ & $0.380 \pm 0.01^{\mathrm{de}}$ & $35.83 \pm 0.38^{9}$ & $20.18 \pm 0.08^{\mathrm{cde}}$ \\
\hline ICCV92944 & $1.38 \pm 0.13^{\mathrm{bc}}$ & $0.300 \pm 0.03^{\mathrm{de}}$ & $0.353 \pm 0.01^{\text {cde }}$ & $34.42 \pm 0.80^{\mathrm{fg}}$ & $23.05 \pm 1.12^{\mathrm{ef}}$ \\
\hline ICC3137 & $0.97 \pm 0.15^{\mathrm{ab}}$ & $0.298 \pm 0.04^{\mathrm{de}}$ & $0.300 \pm 0.03^{\mathrm{abc}}$ & $26.67 \pm 1.04^{\mathrm{e}}$ & $13.96 \pm 0.08^{\mathrm{a}}$ \\
\hline ICCL86111 & $1.54 \pm 0.33^{c}$ & $0.233 \pm 0.02^{\mathrm{bcd}}$ & $0.250 \pm 0.02^{\mathrm{a}}$ & $32.50 \pm 0.50^{f}$ & $17.10 \pm 0.15^{b c}$ \\
\hline PG186 & $1.27 \pm 0.12^{\mathrm{abc}}$ & $0.463 \pm 0.01^{\dagger}$ & $0.410 \pm 0.02^{\mathrm{e}}$ & $22.75 \pm 0.25^{d}$ & $30.92 \pm 0.20^{\mathrm{s}}$ \\
\hline $\mathrm{Gl}^{\#}$ & $-361^{\mathrm{NS}}$ & -438 NS & $-219^{N S}$ & $.287^{\mathrm{NS}}$ & $-633^{*}$ \\
\hline
\end{tabular}

*Means in a column followed by the same letter(s) do not differ significantly at the 5\% level by Tukey's HSD test; "Correlation with growth index (GI). Significant at 5\%, NS- Non-significant; TPC- Total phenolic content, TFC- Total flavonoid content, TPCC- Total proanthocyanidin content, PC- Protein content and TIC- Trypsin inhibitor content. 
Gas Chromatography-Mass Spectrometry (GC-MS) based Metabolomics of Promising Chickpea Genotypes against...

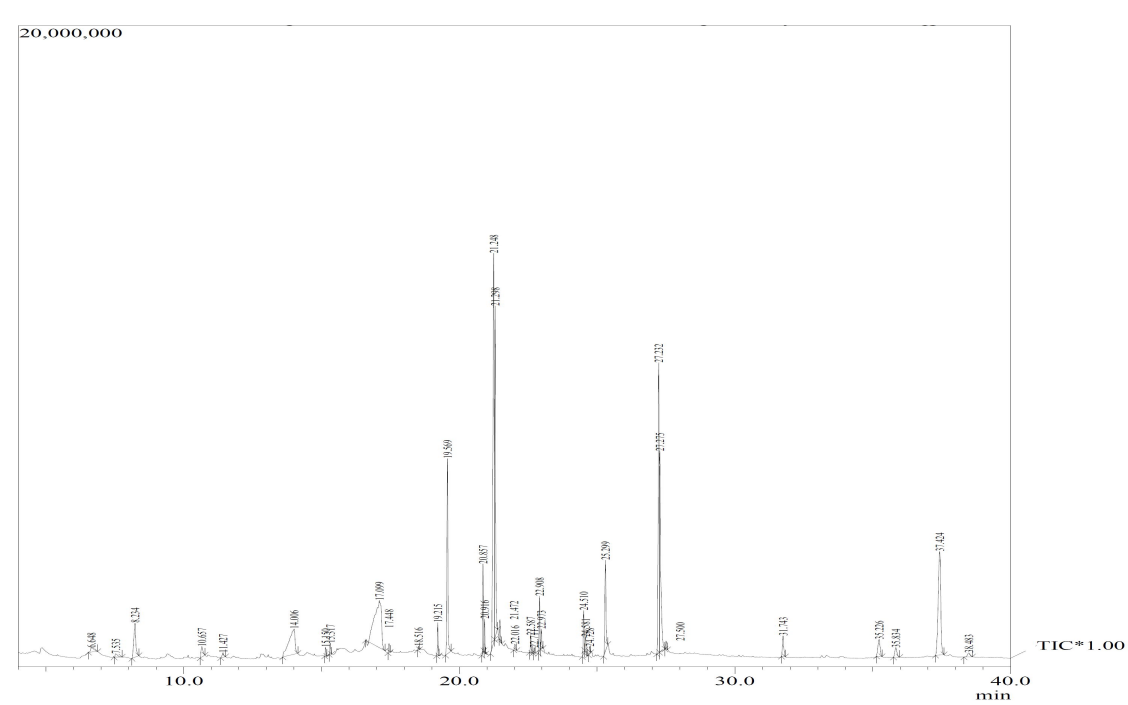

Fig 2: GC-MS chromatogram of methanol mature seed extract of genotype ICCV92944. 20,000,000

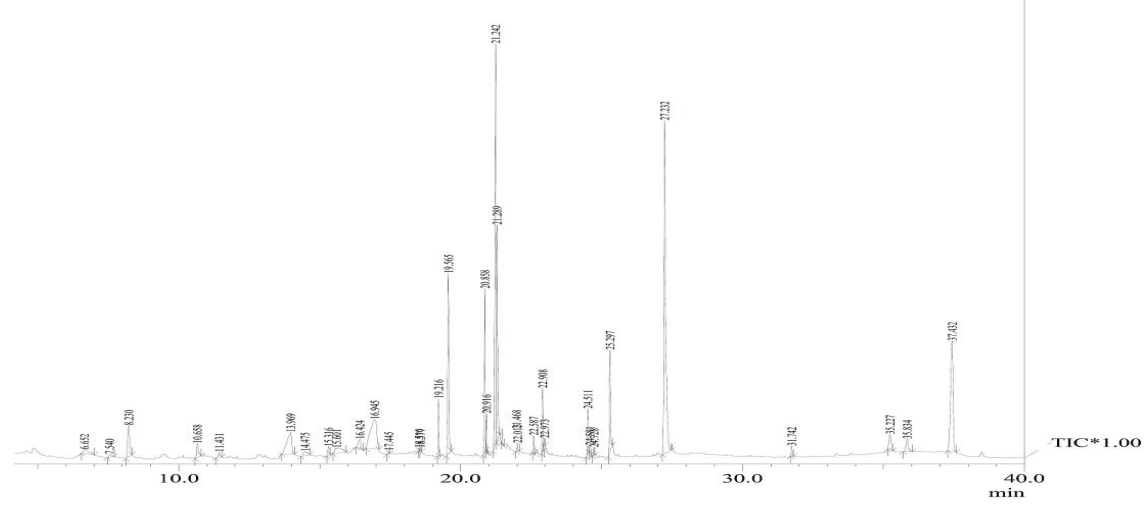

Fig 3: GC-MS chromatogram of methanol mature seed extract of genotype $\mathrm{HC}$.

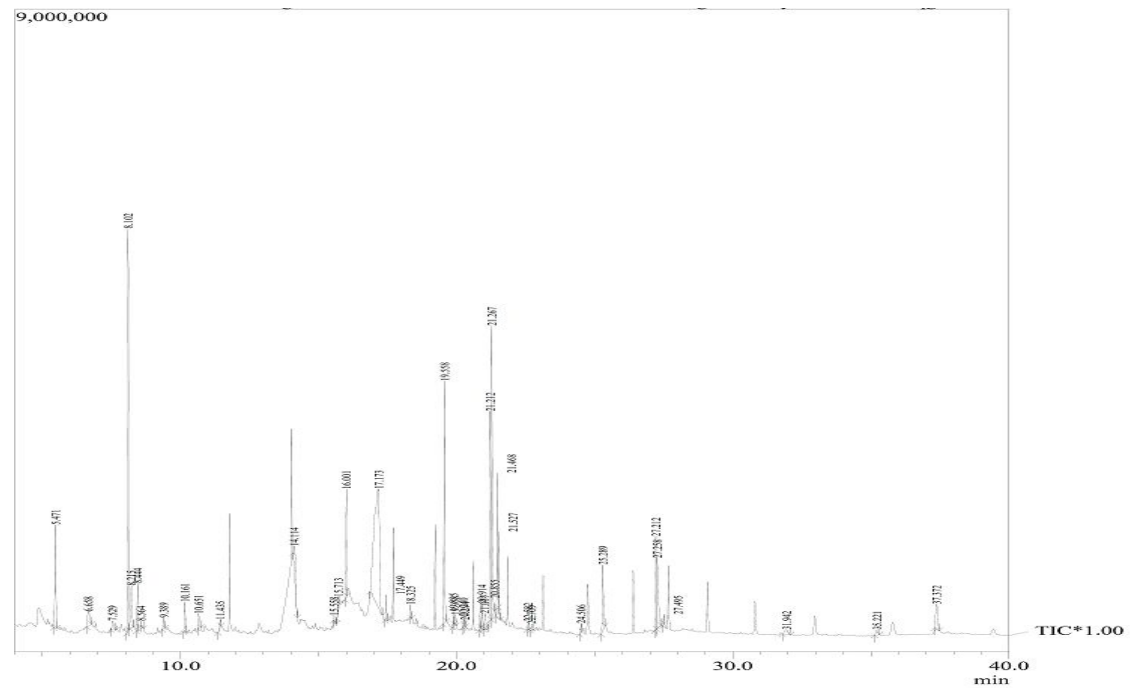

Fig 4: GC-MS chromatogram of methanol mature seed extract of genotype JG11. 


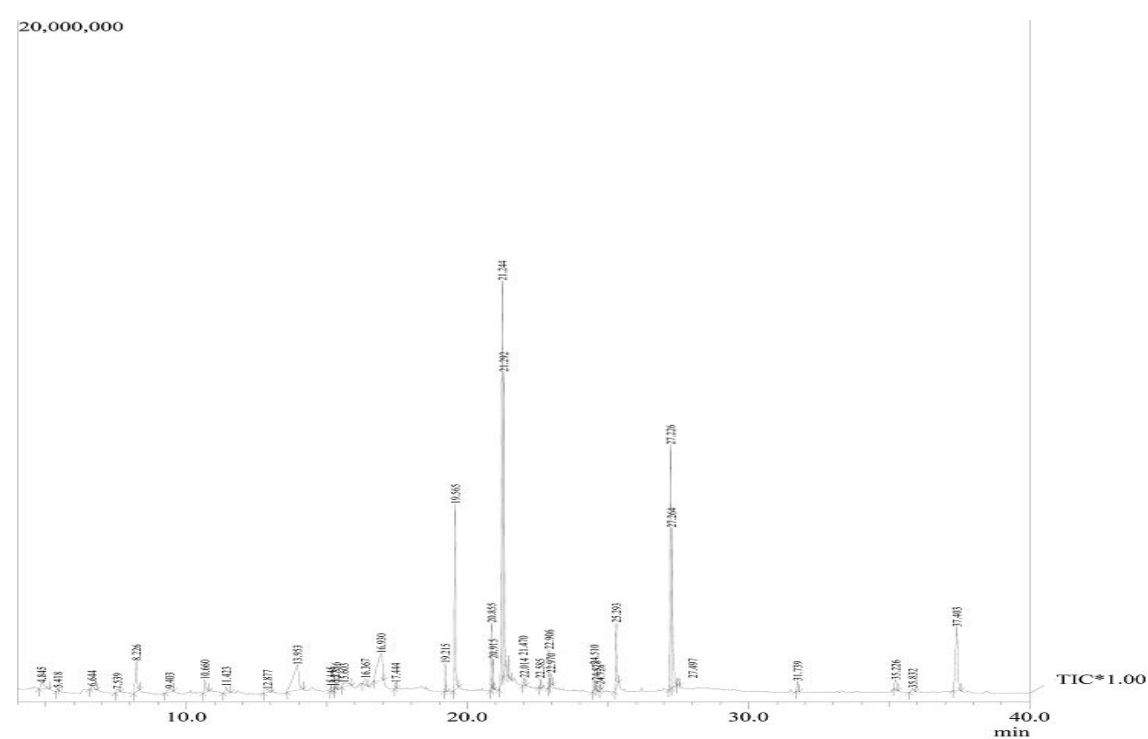

Fig 5: GC-MS chromatogram of methanol mature seed extract of genotype ICC3137.

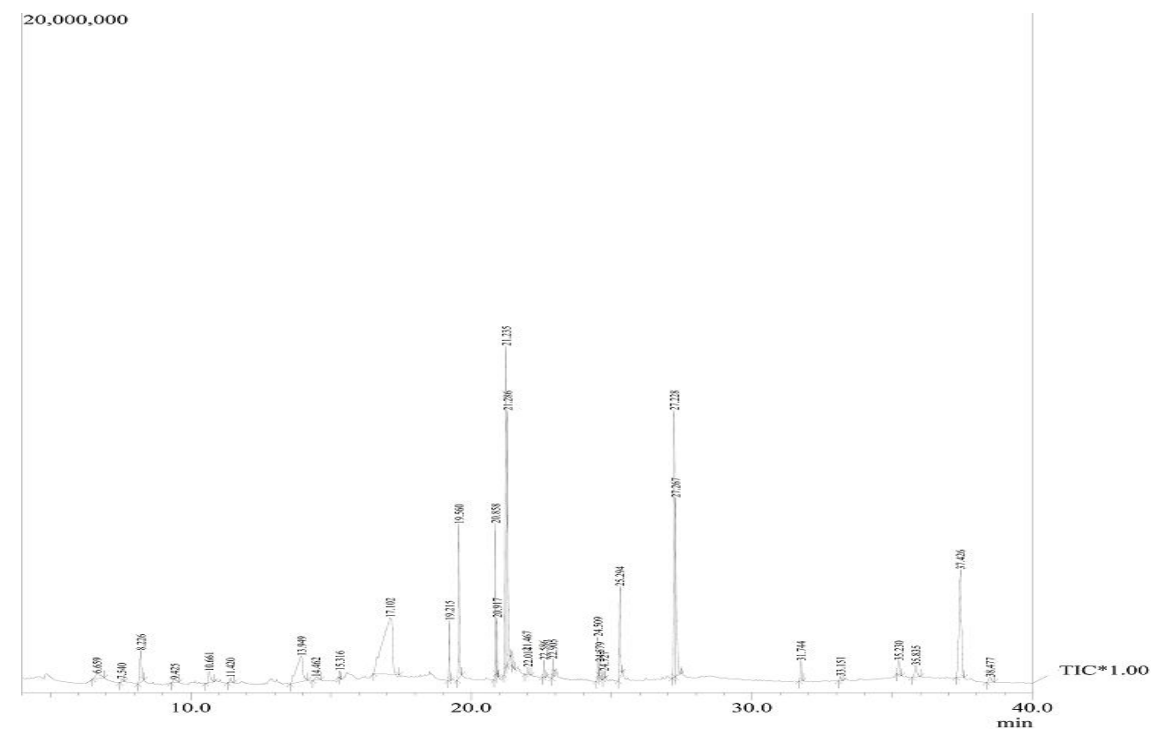

Fig 6: GC-MS chromatogram of methanol mature seed extract of genotype PG186.

Table 4: Bioactive compounds identified from mature seed extract of ICCV92944, HC1, ICCV3137, PG186 and JG11 through GC-MS analysis.

\begin{tabular}{|c|c|c|c|c|c|c|c|c|}
\hline \multirow{2}{*}{$\begin{array}{l}\text { Retention } \\
\text { time }\end{array}$} & \multirow{2}{*}{ Name } & \multirow{2}{*}{$\begin{array}{l}\text { Chemical } \\
\text { formula }\end{array}$} & \multirow{2}{*}{$\begin{array}{c}\text { Molecular weight } \\
(\mathrm{g} / \mathrm{mol})\end{array}$} & \multicolumn{5}{|c|}{ Peak area \% } \\
\hline & & & & ICCV92944 & $\mathrm{HC} 1$ & ICCV3137 & PG186 & JG11 \\
\hline 15.317 & Quinoline, 4-methyl- & $\mathrm{C}_{10} \mathrm{H}_{9} \mathrm{~N}$ & 143 & 0.32 & 0.44 & 0.14 & 0.17 & - \\
\hline 17.448 & Tetradecanoic acid & $\mathrm{C}_{14} \mathrm{H}_{28} \mathrm{O}_{2}$ & 228 & 0.23 & 0.11 & 0.18 & 0.12 & - \\
\hline 20.857 & $\begin{array}{l}\text { 9,12-Octadecadienoic } \\
\text { acid, methyl ester }\end{array}$ & $\mathrm{C}_{19} \mathrm{H}_{34} \mathrm{O}_{2}$ & 294 & 2.05 & 20.86 & 1.92 & 3.55 & 0.51 \\
\hline 20.916 & 9-Octadecenoic acid (Z)- & $\mathrm{C}_{19} \mathrm{H}_{36} \mathrm{O}_{2}$ & 296 & 0.70 & 0.87 & 0.75 & 1.24 & - \\
\hline 25.299 & $\begin{array}{l}\text { Hexadecanoic acid, 2- } \\
\text { hydroxy-1-(hydroxyl-methyl) } \\
\text { ethyl ester }\end{array}$ & $\mathrm{C}_{19} \mathrm{H}_{38} \mathrm{O}_{4}$ & 330 & 3.53 & 4.11 & 3.00 & 3.37 & 1.45 \\
\hline 37.424 & $\gamma$-Sitosterol & $\mathrm{C}_{29} \mathrm{H}_{50} \mathrm{O}$ & 414 & 9.11 & 9.12 & 6.37 & 9.03 & 1.49 \\
\hline
\end{tabular}


Among the various phytoconstituents identified $\gamma$-Tocopherol; 1,4-Dioxin, 2,3-dihydro-5,6-dimethyl-; 3-Cyclopentylpropionic acid; 2-dimethylaminoethyl ester; 5-Hydroxymethylfurfural; 9,12-Octadecadienoic acid, methyl ester; 9,12-Octadecadienoyl chloride; (Z, Z)-, 9,12Octadecadienoic acid (Z,Z)-, 9-Octadecenoic acid (Z)-, methyl ester; Acetic acid, 1-(2-methyltetrazol-5-yl) ethenyl ester; Ergost-5-en-3-ol, (3ß)-; Guanosine; 6-oxo-heptanoic acid; Hexadecanoic acid; 2-hydroxy-1- (hydroxymethyl) ethyl ester; Hexadecanoic acid, methyl ester; Mome inositol; Octanamide, N- (2-hydroxyethyl)-; Octanoic acid, 2-dimethyla minoethyl ester and Quinoline, 4-methyl- were common among all the four genotypes. Compounds with pesticidal properties viz. Quinoline, 4-methyl-; Tetradecanoic acid; 9, 12- Octadecadienoic acid, methyl ester; 9-Octadecenoic acid (Z)-;Hexadecanoic acid, 2-hydroxy-1 (hydroxymethyl) ethyl ester and $\gamma$-Sitosterol have been detected in genotypes ICCV92944, HC1, ICC3137 and PG186 (Table 4).

9-Octadecenoic acid (Z) found in $\mathrm{HC} 1$ genotype was responsible for resistance against $C$. chinensis. Compounds 9,12-Octadecadienoic acid and methyl ester known to act as insectifuge (Arora and Kumar, 2018). Guoqing et al. (2001) reported the oviposition deterring and repellent activity in HC1. Pesticidal properties of Hexadecanoic acid, methyl ester had been reported by Chandrasekaran et al. (2011). Pesticide activity of $n$-Hexadecanoic acid was reported by Zayed et al. (2014). Insecticidal and antimalarial properties had been reported from Quinoline, 4-methyl (Morgan et al. 2002). Sivakumar et al. (2011) reported the larvicidal and repellent activity of tetradecanoic acid.

\section{CONCLUSION}

In this investigation eleven chickpea genotypes were screened against $C$. chinensis using no choice test under storage conditions. The minimum number of eggs on smooth and brown bold sized seeds of NBeG1004 and ICCV92944 specifies that its resistance based on non-preference for oviposition. HC1 with high phenolic, flavonoid, protease inhibitors content and the metabolite 9-Octadecenoic acid (Z)- was found for resistance against $C$. chinensis. From the current study it has been observed that not a single variety showed complete resistance to the $C$. chinensis. But, it is expected that the source of biophysical and biochemical resistance in genotypes ICCV14872, ICC07104, ICCV97105 and ICCV92944; metabolite in $\mathrm{HC1}$, could have a potential to monitor and can be used in future IPM programs against C. chinensis at storage level.

\section{REFERENCES}

Ahmad, J., Maleque, M.A., Islam, M.S. and Bhuiyan, M.A.H.L. (2016). Evaluation of indigenous plant powder against pulse beetle (Callosobruchus chinensis L.) of stored chickpea. Journal of the Sylhet Agricultural University. 3(2): 215-221.
Arora, S. and Kumar, G. (2018). Comparative morphological screening of some species of Cenchrus L. (Poaceae) from Thar Desert of Rajasthan, India. Annals of Plant Sciences. 7(4): 2175-2178.

Chandrasekara, A. and Shahidi, F. (2010). The content of insoluble bound phenolics in millets and their contribution to anti oxidant capacity. Journal of Agricultural and Food Chemistry. 58: 6706-6714.

Chandrasekaran, M., Senthilkumar, A. and Venkatesalu, V. (2011). Anti-bacterial and antifungal efficacy of fatty acid methyl esters from the leaves of Sesuvium portulacastrum L. European Review for Medical and Pharmacological Sciences. 15(7): 775-780.

Deepika, K.L., Singh, P.S., Singh, S.K. and Saxena, R.P.N. (2020). Biochemical basis of resistance against pulse beetle, Callosobruchus chinensis (L.) in stored chickpea geno types. Journal of Experimental Zoology, India. 23(2): 1175-1180.

Ghosal, T.K., Dutta, S., Senapti, S.K. and Deb, D.C. (2004). Role of phenol contents in legume seeds and its effect on the biology of Callosobruchus chinensis. Annals of Plant Protection Sciences. 12(2): 425-475.

Guoqing, L., Zhaojum, H., Lili, M., Xiaoran, Q., Changkun, C. and Yinchnag, W. (2001). Natural oviposition chemicals in female cotton bollworm, Helicoverpa armigera (Hübner). Journal of Insect Physiology. 47: 951-956.

Hajela, N., Sharma, A.H., Sharma, S., Rao, D.N. and Hajela, K. (1999). Studies on a double headed protease inhibitor from Phaseolus mungo. Journal of Plant Biochemistry and Bio Technology. 8: 57-60.

Howe, R.W. (1971). A parameter for expressing the suitability of an environment for insect development. Journal of Stored Product Research. 7: 63-65.

Jackai, L.E.N. and Singh, S.R. (1988). Screening techniques for host plant resistance to insect pests of cowpea. Tropical Grain Legume Bulletin. 35: 2-18.

Kamble, S.M., Bagde, A.S. and Patil, R.R. (2016). Oviposition pref erence of pulse beetle on different cultivars of chickpea. Journal of Global Biosciences. 5(6): 4197-4201.

Khattab, R.Y. and Arntfield, S.D. (2009). Nutritional quality of le gume seeds as affected by some physical treatments. LWT - Food Science and Technology. 42: 1113-1118.

Kim, D.O., Jeomg, S.W. and Lee, C.Y. (2003). Antioxidant capac ity of phenolic phytochemicals from various cultivars of plums. Food Chemistry. 81(3): 321-326.

Lal, R.R. and Verma, P. (2007). Post-harvest Management of Pulses. Indian Institute of Pulse Research, Kanpur. pp. 26.

Landerito, E.O., Mendoza, E.M., Laurena, A.C. and Garcia, R.N. (1993). Physicochemical and biochemical factors in mungbean [Vigna radiata (L.) Wilczek] and black gram (Vigna mungo) associated with bruchid (Callosobruchus chinensis L.) resistance. Philippine Journal of Crop Science. 18(3): 153-63.

Liu, D.G. and Trumble, J.T. (2007). Comparative fitness of invasive and native populations of the potato psyllid, Bactericerca cockerelli. Entomologia Experimentalis et Applicata. 123: 35-42. 
Lowry, O.H., Rosebrough, N.J., Farr, A.L. and Randall, R.J. (1951). Protein measurement with the folin phenol reagent. Journal of Biological Chemistry. 193: 265-275.

Malaikozhundan, B. and Thiravia, R.S. (2012). A study on the de velopmental biology of Callosobruchus maculatus (Fabricius) in different pulses. Legume Research. 35(2): 159-163.

Merga, B. and Haji, J. (2019). Economic importance of chickpea: production, value and world trade. Cogent Food and Agriculture. 5: 1615718.

Morgan, L.R., Jursic, B.S., Hooper, C.L., Neumann, D.M., Thangaraj, K. and LeBlanc, B. (2002). Anticancer activity for 4, 4'dihydroxybenzophenone-2, 4-dinitrophenylhydrazone (A007) analogues and their abilities to interact with Lymphoendothelial cell surface markers. Bioorganic and Medical Chemistry Letters. 12(23): 3407-3411.

Raghuwanshi, P.K., Sharma, S., Bele, M. and Kumar, D. (2016). Screening of certain gram accessions against Callosobruchus chinensis L. (Coleoptera: Bruchidae). Legume Research. 39: 651-653.

Reddy, M.S.S. and Agnihotri, M. (2018). Screening of chickpea tolerant genotypes against pod borer Helicoverpa armigera (Hübner) at hotspot Pantnagar. International Journal of Chemical Studies. 6(4): 590-594.

Shaheen, F.A., Khaliq, A. and Aslam, M. (2006). Resistance of chickpea (Cicer arietinum L.) cultivars against pulse beetle. Pakistan Journal of Botany. 38(4): 1237-1244.

Sivakumar, R., Jebanesan, A., Govindarajan, M. and Rajasekar, P. (2011). Larvicidal and repellent activity of tetradecanoic acid against Aedes aegypti (Linn.) and Culex quinquefasciatus (Say.) (Diptera: Culicidae). Asian Pacific Journal of Tropical Disease. 4(9): 706-710.
Somta, P., Talekar, N.S. and Srinives, P. (2006). Characterization of Callosobruchus chinensis (L.) resistance in Vigna umbellata (Thunb.) Ohwi and Ohashi. Journal of Stored Products Research. 42(3): 313-327.

Soumia, P.S., Srivastava, C., Dikshit, H.K. and Pandi, G.G.P. (2017). Screening for resistance against pulse beetle, Callosobruchus analis (F.) in greengram [Vigna radiata (L.) Wilczek] accessions. Proceedings of the National Academy of Sciences, India Section B: Biological Sciences. 87(2): 551-558.

Sulehrie, M.A.Q., Golob, P., Tran, B.M.D. and Farrell, G. (2003). The effect of attributes of Vigna spp. on the bionomics of Callosobruchus maculatus. Entomologia Experimentalis et Applicata. 106: 159-168.

Sun, B., Richardo-da-Silva, J.M. and Spranger, I. (1998). Critical factors of vanillin assay for catechins and proanthocyanidins. Journal of Agricultural and Food Chemistry. 46: 42674274.

Tamhane, V.A., Chougule, N.P., Giri, A.P., Dixit, A.R., Sainani, M.N. and Gupta, V.S. (2005). In vivo and in vitro effect of Capsicum annum proteinase inhibitors on Helicoverpa armigera gut proteinases. Biochimica et Biophysica Acta-General Subjects. 1722(2): 156-167.

Zayed, M.Z., Ahmad, F.B., Ho, W. and Pang, S. (2014). GC-MS analysis phytochemical constituents in leaf extract of Neolamarckia cadamba (Rubiaceae) from Malaysia. In ternational Journal of Pharmacy and Pharmaceutical Sciences. 6(9): 123-127. 